1 Zerhouni EA, Naidich DP, Stitik FP, Khouri NF, Siegelman SS. Computed tomography of the pulmonary parenchyma. II. Interstitial disease. J Thorac Imaging 1985;1:54-64.

2 Strickland B, Strickland NH. The value of high definition, narrow section computed tomography in fibrosing alveolitis. Clin Radiol 1988;39:589-94.

3 Bergin CJ, Muller NL. CT of interstitial lung disease: a diagnostic approach. Am J Radiol 1987;148:8-15.

4 Staples CA, Muller NL, Vedal S, Abboud R, Ostrow D, Miller RR. Usual interstitial pneumonia: correlation of CT with clinical, functional, and radiologic findings. Radiology 1987;162:377-81.

5 Muller NL, Miller RR. State of the art: computed tomography of chronic diffused infiltrative lung disease, part I. Am Rev Respir Dis 1990;142:1206-15.

6 Hansell DM, Kerr IH. The role of high resolution computed tomography in the diagnosis of infiltrative lung disease. Thorax 1991;46:77-84.

7 Nakata H, Kimoto T, Nakayama T, Kido MM, Miyazaki N, Narada S. Diffuse peripheral lung disease: Evaluation by high-resolution computed tomography. Radiology 1985; 157:181-5.

8 Staples CA, Gamsu G, Ray CS, Webb WR. High resolution computed tomography and lung function in asbestos workers with normal chest radiograph. Am Rev Respir Dis 1989;139:1502-8.

9 Aberle DR, Gamsu G, Ray CS, Feuerstein IM. Asbestosrelated pleural and parenchymal fibrosis: detection by high-resolution CT. Radiology 1988;166:729-34.

10 Yoshimura H, Hatakeyama M, Otsuji H, Maeda M, Ohishi $\mathrm{H}$, Uchida $\mathrm{H}$, et al. Pulmonary asbestosis: CT study of subpleural curvilinear shadow. Work in progress. Radiology 1986;158:653-8.

11 Akira M, Yamamoto S, Yokoyama K, Kita N, Morinaga $\mathrm{K}$, Higashihara $\mathrm{T}$, et al. Asbestosis: high-resolution CTpathologic correlation. Radiology 1990;176:389-94.
12 Mathieson JR, Mayo JR, Staples CA, Muller NL. Chronic diffuse infiltrative lung disease: $A$ comparison of diagnostic accuracy of CT and chest radiography. Radiology 1989;171:111-6.

13 International Labour Office. International classification of radiographs of pneumoconiosis. Geneva: ILO, 1980 radiographs of pneumoconiosis. Geneva. 2 (O), 1980.

14 Strickland B, Brennan J, Denison DM. Computed tomography in diffuse lung disease: Improving the image. Clinical radiology 1986;37:335-8.

15 Cotes JE. Lung function: assessment and application in medicine. 4th ed. Oxford: Blackwell Scientific 1979.281-7.

16 Wiggins J, Strickland B, Turner-Warwick M. Combined cryptogenic fibrosing alveolitis and emphysema; the value of high resolution computed tomography in assessment. Respir Med 1990;84:365-9.

17 Weiss W. Cigarette smoking, asbestos, and pulmonary fibrosis. Am Rev Respir Dis 1971;104:223-7.

18 Weiss W, Theodas PA. Pleuropulmonary disease among asbestos workers in relation to smoking and type of exposure. J Occup Med 1978;20:341-5.

19 Lilis R, Selikoff IJ, Lerman Y, Seidman H, Gelb SK. Asbestosis: interstitial pulmonary fibrosis and pleural fibrosis in a cohort of asbestos insulation workers: influence of cigarette smoking. Am J Ind Med 1986;10:459-70.

20 Kilburn KH. Clarification of data on the etiological role of cigarette smoking in pulmonary fibrosis. $\mathrm{Am} \mathrm{J}$ Ind $\mathrm{Med}$ 1984;5:421-2

21 Begin R, Cantin A, Berthiaume Y, Boileau R, Peloquin S, Masse S. Airway function in lifelong nonsmoking old asbestos workers. Am J Med 1983;75:631-8.

22 Cohen BM, Adasczik A, Cohen EM. Small airways changes in workers exposed to asbestos. Respiration 1984;45: 296-302.

23 Wright JL, Churg A. Severe diffuse small airways abnormalities in long term asbestos miners. $\mathrm{Br} J$ Ind Med 1985;42:556-9.

\title{
Adventitia
}

\section{My only private patient}

Foolishly I never did private practice. Foolishly because if you don't do private practice you are never going to see Elizabeth Schwarzkoff as a patient, or for that matter Madonna, and the money must come in handy-though when I started a consultant's salary was a living wage.

Almost 30 years ago a posh GP rang me up to say that he was sending me the 14 year old daughter of an American film producer-this on the advice of an American professor of paediatrics I had met in New York. The girl had been diagnosed in New York as having tuberculous glands of the neck and I was to continue her treatment with isoniazid alone. I didn't like the sound of that.

I found a rather sulky girl with bilateral cervical gland enlargement. The glands were quite large, up to about an inch in diameter, not tender, firm, and mobile. Not at all like tuberculous glands. What is more the girl's mother told me that the girl had started menstruating and that during the cycle the glands changed in size quite considerably; that didn't sound like tuberculosis either.

So I started by doing a tuberculin test (the New York diagnosis had been purely clinicalno investigations had been done). It was a Heaf test, the only one available in the chest clinic (a shop near Oxford Circus) and it is a very good test: it requires no skill, it is virtually painless, and, conveniently, it can be read at a week. The response was negative. So it wasn't tuberculosis (atypical mycobacteria as a cause of cervical adenitis had hardly been heard of in Britain at that time)

I rang the posh GP and told him that the girl would have to have a biopsy. The posh GP said he would arrange it. I assumed that this was the usual thing in private practice. He sent her to a urologist! A week or two later the answer came back. It was follicular carcinoma of the thyroid, which apparently is well known to occur in teenage girls. It wasn't well known to me. It was the first I had heard of it and the last. So I rang the posh GP and told him the girl should be sent to Jack Piercy, the surgeon superintendent of New End Hospital in Hampstead. New End was the name of a famous thyroid clinic originally started by London County Council. It had had several great men on its staffamong them Cecil Joll, who wrote a massive surgical textbook on the thyroid; Geoffrey Keynes (the brother of Maynard, the economist), who was the world authority on William Blake, and also Raymond Greene (the brother of Graham, the writer), who had been an Everest climber. Jack Piercy was the greatest of the lot. Two days later the posh GP rang me to say that Sir Ronald Bodley Scott, physician to the Queen, had said that we couldn't do better. I was very chuffed.

Jack Piercy told me in his letter that he had treated 17 similar patients by total thyroidectomy and block dissection of neck and that they had all survived. This girl underwent a successful block dissection of the thyroid. Many years later I heard that she was well (taking thyroxine as replacement therapy, of course).

I sent the film producer a bill for $£ 25$, which he paid by return but with no word of thanks.

I thought, "I will never be as lucky as that again so I'd better not see any more private patients," and I never did. 